Article

\title{
Implications of Fiscal Pressure on the Sustainability of the Equilibrium and Performance of Companies. Evidences in the Rubber and Plastic Industry from Romania
}

\author{
Amelia Bucur ${ }^{1, *}$, Gabriela Dobrotă ${ }^{2,3}$ and Oana Dumitraşcu 4 \\ 1 Faculty of Sciences, Department of Mathematics and Informatics, Lucian Blaga University of Sibiu, \\ Sibiu 550024, Romania \\ 2 Faculty of Economics, Constantin Brâncuşi University of Târgu-Jiu, Târgu-Jiu 210007, Romania; \\ gabi.dobrota70@gmail.com \\ 3 Doctoral School, Lucian Blaga University of Sibiu, Sibiu 550024, Romania \\ 4 Faculty of Engineering, Lucian Blaga University of Sibiu, Sibiu 550024, Romania; \\ oana.dumitrascu@ulbsibiu.ro \\ * Correspondence: amelia.bucur@ulbsibiu.ro; Tel.: +40-074-038-1318
}

Received: 22 February 2019; Accepted: 3 April 2019; Published: 8 April 2019

\begin{abstract}
The relationship between the degree of taxation, the activity of firms and the performance measured by the ability to achieve positive results and to ensure a financial equilibrium has been an important issue in the debate in a great deal of research, but in most of them, the analyses were reported according to a set of factors (inclusive the fiscal degree). This paper comprises an empirical investigation to identify the effects of the degree of taxation on financial stability and the balance of enterprises. An analysis of the degree of taxation and of the economic growth rate in Romania was made in the first part, and, after that, empirical analyzes were conducted on how the volume of taxes, the capital structure and other indicators influences the level of value added as well as the volume of fiscal pressure and the duration of payment of tax liabilities. Using data on the level of macroeconomic taxation, as well as information on financial equilibrium indicators at the level of some representative companies in the field of rubber and plastic processing listed on the stock exchange, a model of the existing relationships between a series of indicators related to financial equilibrium and economic growth rate, fiscal pressure and profitability was produced, using statistical analyses based upon multiple regressions and simulations in SPSS software. The main conclusions show that taxes and fees influence the financial positions of firms by changes in the volume and structure of the capital used, the level of profit/loss, as well as financial equilibrium, at the level of solvency and liquidity. Also, the results extend the understanding of the importance the tax administration in creating added value, ensuring financial equilibrium and good performance in the context of the sustainable development of companies.
\end{abstract}

Keywords: fiscal degree; sustainability; equilibrium; financial policy; regression

\section{Introduction}

A fundamental component of economic policy remains fiscal policy, as it relates to providing the required resources for the state. Of particular importance is the setting of clear and coherent objectives, corresponding to the development period and the implementation of measures to ensure that they are achieved. Optimal tax policies should always take into account the implications of the degree of taxation on the activity of economic agents. The logical nature of fiscal policy decisions implies that 
they are taken in relation to the evolution of economic variables and the choices of society. Moreover, a strong private sector, supported by an optimal economic freedom and a tolerable tax burden, is a real support for economic development. Against this background, the relaxation or increase of fiscal pressure influences the behavior of economic agents acting in the field of intervention. Through fiscal policy promoted by the government, the state is trying to fulfill its social functions. Fiscal policy, through its role of redistributing some national income, may cause a change in the propensity for consumption (it has been demonstrated that there are social categories that devote a greater share of their consumption revenue).

Tax policy has a double meaning for the economic agent. On the one hand, it takes the form of mandatory levies to the state, with direct implications on the company's treasury, which is reflected in the specialized literature under the name of tax burden. On the other hand, the economic operator may try to use the fiscal principles and methods in his own interests, namely to achieve fiscal administration. Thus, in the financial exploitation or investment activities of the enterprise, methods and techniques may be used whose tax incidents more or less obviously offer advantages that result in most cases in a more favorable treasury situation. As a result, the level of tax liabilities is of particular important for any economic operator, exerting a significant influence on business activity, behavior and profit distribution decisions.

Fiscal pressure, in the opinion of some economists, may have a negative impact on the saving and investment process if it is too high, because income tax will affect savings but also investment income. One of these economists is Arthur Laffer, who, in his attempts to determine the fiscal optimum, has highlighted that an increase in fiscal pressure will not necessarily lead to increased tax revenues, but that a decrease therein will generate a larger volume of tax revenues, thus allowing the state to achieve the established or projected economic targets [1].

From the aspects mentioned, it may be concluded that the economic environment is influenced by fiscal policy, both through the level of taxes applied and through the fiscal facilities granted by the state. Since most studies analyze the correlation between the degree of taxation determined at the macroeconomic level and the various characteristics of the firms, such as their size, structure of assets or capital employed, they govern a set of factors for the activity of economic agents; this research tries to provide new arguments on the correlation between the tax policy promoted by the authorities and the state of equilibrium and performance at the level of economic agents. In line with the above-mentioned issues, the research carried out in this paper aims at identifying the effects of the degree of degree taxation on the stability and balance of enterprises. In this respect, an analysis of the degree of taxation and of the economic growth rate in Romania was made in the first phase, while in the second, empirical analyzes were conducted on how the volume of taxes, the capital structure and other indicators influences the level of value added, as well as the volume of fiscal pressure and the duration of payment of tax liabilities.

The remainder of the paper is organized as follows: Section 2 comprises a literature review, Section 3 shows the interdependencies between economic growth and the degree of taxation in Romania; Section 4 presents categories of tax liabilities recorded at the level of economic agents; Section 5 presents research methodology and results, and includes a discussion. Conclusions, research limitations, avenues for future research are outlined in Section 6.

\section{Literature Review}

The implications of the degree of taxation on business activity and financial equilibrium have been analyzed in many recent studies. It is often considered that the impact of fiscal policy is implicit on the business environment, on the capacity to provide the necessary resources for the activity as well as on the quality of the performance of economic agents. Thus, in the literature, this problem is dealt with through models that aim only at identifying correlations between certain elements. Thus, most specialists have attempted to identify the correlation between tax rates and various elements such as capital structure, size of firms or asset structure used, e.g., Richardson and Lanis (2006), Gupta and 
Newberry (1997), Stickney and McGee (1982), Overesch and Voeller D. (2010), Givoly et al. (1992), Clemente-Almendros and Sogorb-Mira (2016), Feld et al. (2013), Doidge and Dyck (2015), Faccio and $\mathrm{Xu}$ (2015), and Heider and Ljungqvist (2015), Parise et al. (2018) etc. [2-12].

There is also analysis of the factors that influence financial equilibrium. Thus, Townsed (2010) showed that financial equilibrium approaches should include both micro- and macro- economic factors [13]. Žager et al. (2012) analyzed the financial performance of SMEs in the Republic of Croatia and showed that it is very important to analyze the balance based on financial reports in small and medium-sized enterprises (SMEs) [14].

Another model of equilibrium is presented by Ji et al. (2013), who examines tax reform in Chinese enterprises in the context of applying a $25 \%$ income tax. The research results showed that the optimal tax rate on a Chinese production company is $21.82 \%$ [15].

Analyzing the behavior of multinational companies, Latorre (2013) builds a general equilibrium model to analyze company performance [16]. The model is applied in the Czech Republic, where direct investment has been very attractive over the last three decades.

Starting from the fact that the economic agents are affected by the paying of the taxes, their tax behavior was also analyzed, considering that it may be of civic compliance with taxes or may be non-compliant, due to ethical, social, or economic, fiscal pressure being the determinant factor. According to the author, fiscal pressure is influenced by the level of taxation, the deductible expenses and the way of determining the tax base, the tax behavior being analyzed according to certain characteristics (the size of the economic agent, the seasonality, the region in which the activity is carried out, the field of activity). However, in this paper, the influence of taxation is considered to be implicit [17]). It is also considered that optimizing the tax burden is an attribute of rational economic agents, which changes their behavior according to the level of fiscal pressure, no longer paying taxes after a certain level. The research was not based on statistical data, but aimed to produce a theoretical game model of the interactions between economic agents and the tax authorities, showing the correlations between fiscal evasion and fiscal pressure [18].

In a recent paper, the authors Kuo et al. (2016) highlight that in order to ensure the strategic balance of companies, carbon emissions should be reduced by raising taxes on increasing these emissions [19]. In order to achieve this, a number of countries have implemented fiscal policies to reduce carbon emissions by setting higher prices for carbon emissions, thus forcing polluting companies to invest in green technologies.

Pitulice et al. (2016) demonstrated that the rate of profit tax exerts a negative influence on financial performance indicators [20]. Brezeanu and Damian (2018) analyzed the evolution of fiscal pressure over the period from 2007-2016 within two groups of countries (developed and emerging countries) and highlighted the fact that in the elaboration of fiscal policies, it is necessary to also take behavioral factors into account [21].

In the past years, many researchers have studied the relationship between fiscal pressure and the sustainability of the equilibrium and performance of companies, as well as the relationship between the responsible and socially sustainable behavior of companies and their financial performance.

In 2018, Simionescu and Dumitrescu examined the relationship between corporate social responsibility practices and company financial performance, using a list of companies found on the Bucharest Stock Exchange (Romania) [22].

According to previous specifications, it is clear that ensuring the sustainable development of society as a whole is significantly influenced by the value created by firms, as the economy and society cannot be separated, and the application of principles of value management within firms can promote the sustainability at the level of the whole globally [23]. Thus, the state of economic performance is considered to be fundamental for its sustainability, with direct implications both on financial performance and on the quality of the products and services provided to clients [24]. 
So, the aim of the present research was to perform an analysis of the influence of the fiscal policy, economic growth and the business environment in terms of financial equilibrium, in the context of a statistical model that makes it possible to show the correlations between them.

To achieve, the following objectives were defined: (i) to present some methodological explanations of the relationship between financial equilibrium and fiscal rate; (ii) to provide an economic and mathematical justification for this relationship in the form of a model; and (iii) to reflect the effects of the fiscal policy promoted by the Romanian authorities on an industry sector. To achieve these goals, we used comparisons, correlations, analyses of regression, trend analyses, and graphic representation.

\section{Interdependencies between the Economic Growth and the Degree of Taxation in Romania}

The financial policy of the firm is directly and indirectly influenced by macroeconomic financial policy through fiscal and monetary instruments, which can be considered factors of external influence. An analysis of the macroeconomic environment in Romania highlights a number of important changes which have occurred over recent decades. An important point of inflection is the moment of enrollment on the trajectory of the market economy, with obvious implications on the political, social, legal and, especially, the economic environment. The measures adopted by the authorities, which often occurs without their being correlated with economic reality (the business environment has constantly faced important legislative, organizational, financial, functional, etc. changes that have necessitated continuous adaptation), have proven themselves not to be a basis for economic development. Negative effects, such as rising inflation, trade balance deficit or public debt, attracting a low volume of foreign investment, increasing liquidity and solvency risk for both the financial and banking sector, as well as the business sector, inadequate predictability and the instability of the legislative system, fiscal instability and tax rate, diminishing purchasing power, the inability to manage crisis situations and assuming risks, etc., constituted characteristics of the Romanian economy in the first decade after the 1989 revolution. A favorable economic development period took place after the year 2000, when certain fiscal measures were adopted which aimed at reducing the fiscal pressure on wages, but also on the direct taxes borne by economic agents. The adoption of the flat tax rate did not have the expected effect of increasing tax revenues. Thus, the income generated by corporate tax did not increase significantly after the year when the quota was implemented, with a noticeable influence on the economic development period. This is supported by a simple analysis of the share of income generated by the corporation tax in the total revenue collected by the State. Between 1990 and 1997, it ranged from 10 to $18 \%$. Subsequently, the trend was oscillating, but with a clear downward trend, reaching $8.3 \%$ in 2007 and $5.85 \%$ in 2017 . It is obvious that the macroeconomic imbalances, the low level of competitiveness, the insufficient development of the business environment, but also the clear tendency of the state to obtain preponderant tax revenues from indirect taxes or the breaches of the tax system speculated by the firms, have further characterized the Romanian economy. Moreover, in 2013 and 2017 (the years in which Romania had one of the largest economic growths in the EU), the share of revenues collected from corporate income tax to GDP registered the lowest level, namely $1.7 \%$. On the other hand, revenues from VAT (value added tax) had a GDP share of $6.4 \%$ in 2017 . However, the most eloquent example of the vulnerability of the Romanian economy to large negative phenomena is the events in the years that followed the global economic crisis. Thus, the deterioration of the financial and economic situation resulted in a decrease of economic growth by over $7 \%$ in 2009 (investments and final consumption decreased by more than $12 \%$ ), generated responses from the economic environment resulting from personnel reductions, salaries or capital allocated to investments. The effects generated in relation to the state were the collection of lower tax revenues and the increase in social protection expenditures. A summary of the evolution of the most important indicators characterizing the economic situation at the macroeconomic level is presented in Table 1 (the minimum and maximum limits for the analyzed range are presented). 
Table 1. Staged evolution of macroeconomic indicators in Romania.

\begin{tabular}{ccccc}
\hline Indicators/Period & $\mathbf{2 0 0 0 - 2 0 0 4}$ & $\mathbf{2 0 0 5 - 2 0 0 8}$ & $\mathbf{2 0 0 9 - 2 0 1 4}$ & $\mathbf{2 0 1 5 - 2 0 1 7}$ \\
\hline Unemployment & {$[6.3 ; 11.2]$} & {$[4.4 ; 5.9]$} & {$[5.2 ; 7.9]$} & {$[4.34 ; 5.12]$} \\
Inflation & {$[11.9 ; 45.7]$} & {$[4.84 ; 9]$} & {$[1.4 ; 6.09]$} & {$[-0.6 ; 1.3]$} \\
Budgetary deficit & {$[-1.1 ;-4]$} & {$[-0.8 ;-4.8]$} & {$[-1.85 ;-2.2]$} & {$[-1.47 ;-2.88]$} \\
Government public debt & {$[22.3 ; 31.2]$} & {$[17.4 ; 19.5]$} & {$[26.7 ; 39.4]$} & {$[37.6 ; 38]$} \\
Rate of real economic growth & {$[2.1 ; 8.3]$} & {$[4.2 ; 7.9]$} & {$[-7.1 ; 3.5]$} & {$[3.9 ; 8.8]$} \\
Fiscal pressure & {$[27.65 ; 29.24]$} & {$[17.9 ; 19.5]$} & {$[17.5 ; 19.5]$} & {$[16.6 ; 19.6]$} \\
\hline
\end{tabular}

Source: systematized data www.mfinante.ro; www.bnr.ro; www.insse.ro.

From the systematized data fluctuations can be observed from one period to the other, which were mainly driven by pro-cyclical fiscal policies, increased consumption in the context of wage increases, or as a result of monetary policy measures. Unfortunately, the increase in the tax rate or the implementation of new fiscal obligations have been and remain frequent measures. In addition, repeated changes in the tax legislation and the adoption of controversial measures (minimum tax, passage of contributions from employer to employee, the establishment of forms disputed by taxpayers based on generated ambiguities etc.) remain weaknesses of the Romanian tax system. At the same time, the reaction of the economic environment is always the same: evasion, reduction of activity, redundancies or price hikes for marketed goods, executed works or services.

These aspects can also be highlighted by the analysis of the degree correlation between taxation and economic growth, highlighted in Figure 1.

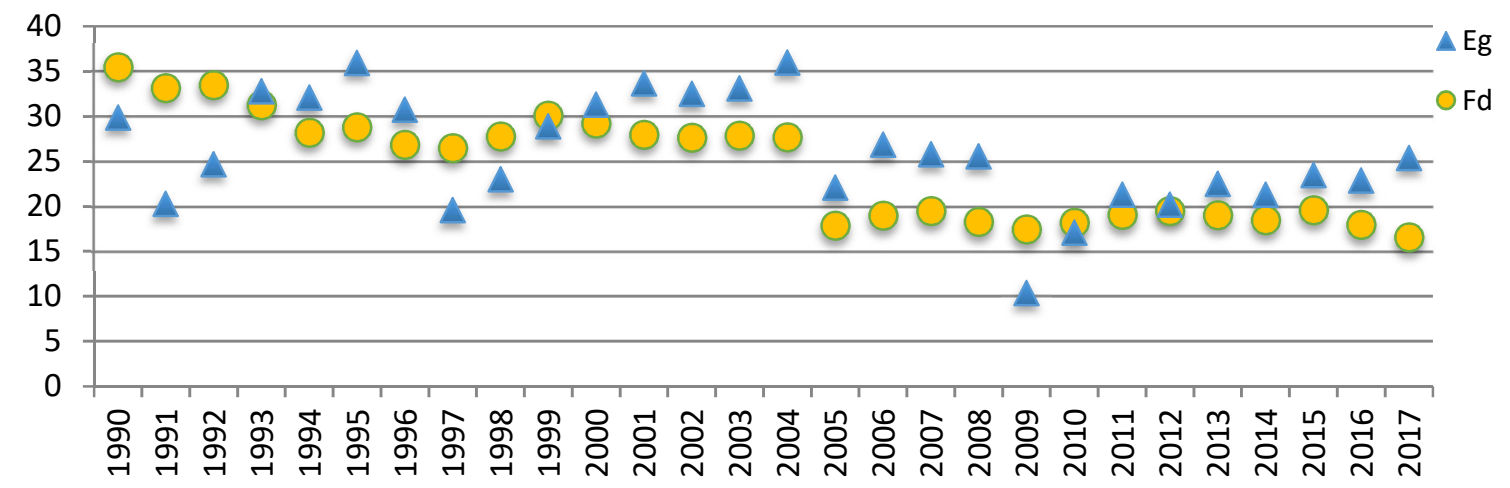

Figure 1. Trends in the evolution of the economic growth rate and of the fiscal degree. Eg is economic growth rate, and Fd is fiscal degree, calculated by reporting tax revenue to GDP. Source: own achievement based on date on www.mfinante.ro; www.insse.ro.

It can be observed that between the measures of fiscal policy and economic growth, a connection exists, like an economic-fiscal spiral (economic growth-higher tax revenues-lower tax pressure-stimulation of economic growth) [25].

Even if there is apparently a tendency to reduce tax rates against the background of a higher rate of economic growth (supported by consumption and concealing major fiscal imbalances), it should not be forgotten that this is also determined by the low levels of collection. In addition, the rate of economic growth is influenced by a set of factors (taxation remains an extremely important one). Testing the correlation between the two indicators for a 10-year period did not result in a direct link, which demonstrated the validity of previous statement.

Against this background, it is obvious that an extremely important issue for the economic environment is taxation. Managers perceive taxation as a problem with major implications for company competitiveness and performance. In fact, fiscal policy is considered to be the greatest risk to growth and macroeconomic stability. In Romania, the extremely large number of legislative changes (over 290 only in 2017) led to a process of fiscal instability, with obvious repercussions on the 
business environment and, in particular, on SMEs. Only by shifting the contributions from employers to employees will negative situations be recorded for the last category, by diminishing the net income or even by registering "negative income" (for part-time activities). Obviously, companies will face a shortage of staff while the state will see declines in the amounts of revenue collected from taxes and increases in public spending. The same situation was observed in 2018, when 236 amendments were made to the fiscal legislation, with clear negative effects on the business environment: the increase in the level of taxation; a high level of bureaucracy generated by the large number of tax returns, documents and situations imposed by tax authorities; the need to adapt to new legislative changes in a relatively short time (the time between legalizing changes and the need for their implementation being very short) ; salary increases with implications for staff restructuring. In addition, another normative act adopted at the end of 2018 generated a lot of negative business debates and reactions, considering that "greed tax" ( $2 \%$ on banks' financial assets) represents an attempt to achieve the fiscal policy by monetary policy, the effects of which are harmful to the population and to economic agents.

In this context, the perception of taxpayers is that the level of taxation is high, justified both by the amount of tax liabilities and by the large number of taxes and fees. However, Romania is positioned below the European average in terms of taxation. Thus, from the analysis of the information provided by Eurostat in 2016, France and Denmark recorded taxation of over $47 \%$, while for Romania, the level was only $26 \%$ (Figure 2 ).

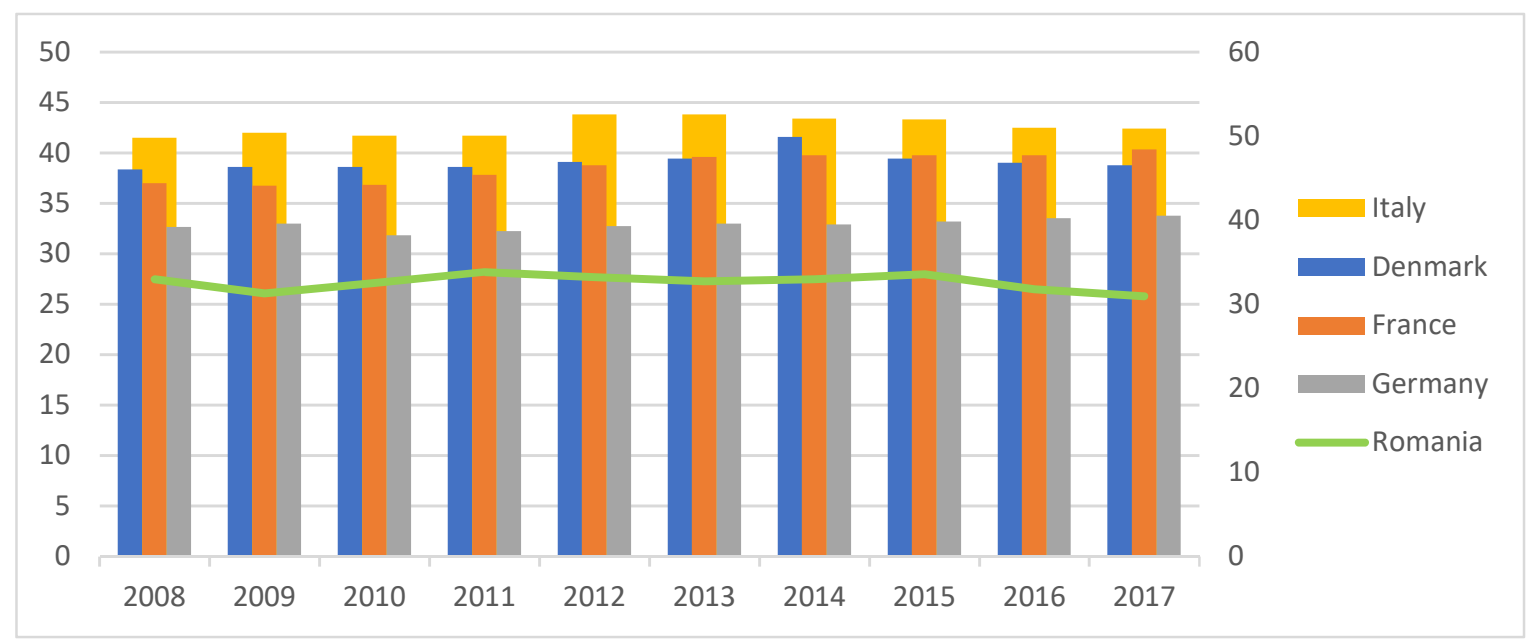

Figure 2. The level of fiscal degree in the period 2007-2017. Source: own achievement based on data from www.eurostat.eu.

The situation was the same in the following years. In accordance with a report by the World Bank Group, in 2018, in Romania, the total tax rate, which measures the share of taxes and contributions incurred by a firm as a percentage of profit, was $38.4 \%$ below the EU average (39.6\%) and the global $(40.5 \%)$ [26]. How is this situation justified? Obviously, comparison is not relevant considering the degree of development of the countries concerned. In addition, in Romania, the granting of tax exemptions, for categories of persons or institutions carrying out operations that are in GDP (for example, public institutions are exempted from paying for public procurement, the incomes from the sale of objects of cult of the cult units are non-taxable income, in the case that these are used for investments, modernization, etc.) leads to a distortion of the calculation of the real size of the taxation degree. As a result, the effect of promoting a fiscal policy that puts pressure on the business environment can only be the growth of the underground economy and the lowering of the collection of taxes and duties (statistical data show a close link between the increase in fiscal pressure and the economy underground). In addition, the statistical data show an increase in the number of suspensions $(10.12 \%)$ and dissolutions $(10.13 \%)$ in the activity of economic agents, for the year 2018 compared to the previous year. 


\section{Categories of Tax Liabilities Recorded at the Level of Economic Agents Which Influence the Equilibrium and the Performances}

An extremely important aspect at any economic level is the planning and management of financial resources so as to avoid bad debts or high financing costs that affect performance and financial equilibrium. In practice, a correlation of current assets and liabilities can avoid the risk of non-payment of short-term payment obligations. Moreover, ensuring an optimal ratio between the rotation of the capital items, the level of profitability recorded and the liquidity, solvency and financial stability ratios can be considered the key to financial equilibrium for economic agents. Consequently, the financial equilibrium is identified at the level of the correlation between the financial resources that can be obtained with a minimum level of costs and related risks and the need for financial resources that ensure the achievement of the proposed objectives. In this context, we can consider the following relationship expressing the content of the financial equilibrium:

$$
\mathrm{RT}=\mathrm{Cc}+\mathrm{I}+\mathrm{Cit}+\mathrm{Rd}
$$

where: RT represent the resources which can be used at the level of companies (equity, borrowed capitals on short, medium or long term); $\mathrm{Cc}$ the resources necessary for the current consumption related to the performed activity; Cit the expenses with taxes and fees; and $\mathrm{Rd}$ the amounts required to repay loans and pay of interests.

From this relationship, we can see that the steady state can be affected by a high level of taxation. In this context, a sustainable development that determines the economic value of a firm, a required performance and a positive impact on the macroeconomic environment, can be ensured by promoting an optimal fiscal policy which ensures the achievement of the state's strategic objectives, and, at the same time, to establish a level of tax obligation that does not affect the ability to self-finance, future development and maintaining the balance of economic agents. Consequently, we can define a sustainable equilibrium both from with the goal of maintaining an adequate balance between resources and funding needs over a long period of time as well as from the point of view of the three corresponding components (economic, environmental and social), because, in a case of a higher degree of taxation, there will be a trend of tax evasion or of securing higher profits by eliminating or reducing spending on environmental protection, salaries (dismissal of employees) or social spending.

An analysis of the main categories of taxes, taxes and mandatory contributions highlights both their large number and the implications they have for the financial results of the economic agents or their employees. Thus, firms have to bear tax obligations (direct and indirect taxes), social contributions and special fund contributions. Employees pay taxes on wages and social contributions, while shareholders have to pay dividend taxes. At the level of economic agents, tax liabilities can be identified, but so can their effects (Table 2).

It can be seen that the profit tax influences both the result of the exercise and the treasury of the firm (through the payment obligations). The State intervenes in determining the net outcome, as it does not allow deductions on any category of expenditure. Thus, corporate tax expense, fines, late payments or other expenses that exceed the limits set by law are deemed to be non-deductible and are added to the gross result of the exercise. In this way, the state wishes to encourage economic agents to properly manage their activity and to limit wastage or attempts to avoid taxing by unjustifiably increasing expenditures.

For the management of the firm, it is of particular importance to analyze some indicators that provide information about tax burden. Thus, an important indicator is fiscal pressure, which is dimensioned by reporting tax liabilities to turnover or value added.

The average payout period of the tax obligations and the mandatory contributions allows the determination of the average number of days when the tax liabilities are paid through revenues from sales. This indicator is useful in analyses made to identify the efficiency and liquidity of economic agents. 
Table 2. Tax and social obligations with impact on the tax burden on firms and their effects.

\begin{tabular}{|c|c|c|}
\hline Categories of Obligations & Indicator Affected & Influence Mode \\
\hline Profit tax & $\begin{array}{l}\text { Outcome of the exercise; } \\
\text { Cash-flow-ul }\end{array}$ & $\begin{array}{l}\text { Through the method of determination; } \\
\text { the facilities granted; the possibility of } \\
\text { carrying forward tax losses } \\
\text { Payment of the tax liability }\end{array}$ \\
\hline VAT & $\begin{array}{l}\text { Outcome of the exercise; Economic } \\
\text { profitability; Return on Equity } \\
\text { (Pro rata is less than } 100 \% \text { or the } \\
\text { firm is not paying VAT); } \\
\text { Liquidity and Solvency of the Firm }\end{array}$ & $\begin{array}{c}\text { Increase in operating expenses and decrease } \\
\text { in accounting result and profitability rates } \\
\text { Payment of value added tax }\end{array}$ \\
\hline Customs duties & Expenditure of the firm & By cost (included in the cost of goods) \\
\hline Excise duties & Expenditure of the firm & $\begin{array}{l}\text { By price (included in the purchase price of } \\
\text { imported goods) }\end{array}$ \\
\hline Taxes and local taxes & $\begin{array}{l}\text { Outcome of the exercise; } \\
\text { Company liquidity }\end{array}$ & $\begin{array}{l}\text { By operating expenses } \\
\text { By payment }\end{array}$ \\
\hline Social contributions & $\begin{array}{l}\text { Performance indicators } \\
\text { Firm liquidity }\end{array}$ & $\begin{array}{l}\text { Expenditure on staff } \\
\text { By payment }\end{array}$ \\
\hline
\end{tabular}

\section{Research Methodology and Results}

\subsection{Data and Results}

This section analyzes the indicators that provide information on the efficiency of the activity carried out in the context of registering tax liabilities in the form of corporate tax and other taxes or duties. Also, modeling of the existing relations between a series of indicators related to financial equilibrium and economic growth rate, fiscal pressure and profitability is made. The indicators used and the calculation formulas are set out in Table 3.

Table 3. Indicator used and calculation formulas.

\begin{tabular}{ccc}
\hline Indicator & Formula & Semnification \\
\hline Value added & $\mathrm{VA}=\mathrm{Vpc}-(\mathrm{Cm}+\mathrm{Acm}+\mathrm{Acea}+\mathrm{Cpe})$ & $\begin{array}{c}\text { Vpc-volume of production and marketing } \\
\text { Cm - expenditure on raw materials and } \\
\text { materials; Acm - other material expenses; } \\
\text { Acea-other external expenditure (energy and } \\
\text { water }) ; \text { Cpe-Expenditure on external services }\end{array}$ \\
\hline Degree of taxation & $\mathrm{Gf}=\mathrm{Cit} / \mathrm{CA} \times 100$ & $\begin{array}{c}\text { Cit-Expenses with taxes and fees; } \\
\text { CA-Turnover }\end{array}$ \\
\hline General liquidity rate & $\mathrm{Rlg}=\mathrm{Ac} / \mathrm{Dc}$ & $\begin{array}{c}\text { Ac-current assets; } \\
\text { Dc—current debts }\end{array}$ \\
\hline Solvency rate & $\mathrm{Rs}=\mathrm{AT} / \mathrm{DT}$ & $\begin{array}{c}\text { AT-Total assets } \\
\text { DT-Total debts }\end{array}$ \\
\hline Equity rate & $\mathrm{Rkpr}(\%)=(\mathrm{PN} / \mathrm{Kpr}) \times 100$ & $\begin{array}{c}\text { PN-Net income; } \\
\text { Kpr-Equity }\end{array}$ \\
\hline $\begin{array}{c}\text { The average duration of } \\
\text { payment of tax obligations }\end{array}$ & $\mathrm{Dm}=\mathrm{Of} \times 360 / \mathrm{CA}$ & Of- Tax obligations paid \\
\hline
\end{tabular}

Added value is an extremely important economic indicator because it allows the determination of the plus of value generated by the use of technical, human and financial capital, subject to the recording of an over-unity ratio between the revenue generated by the sales and the related consumption. The arguments for using this indicator in financial analyses are reflected by a number of issues, including the following: it quantifies the effort made by the economic operator to obtain production; allows identification of the possibility of remuneration of employees, creditors or payment of tax obligations; offers the possibility of assessing the economic operator's ability to obtain the finite 
product with the lowest volume of third party (other entities); allows to identify the degree of use of the factors of production. For example, the added value is an indicator that expresses the increase in value resulting from the use of factors of production, in particular labor and capital, over the value of goods and services from third parties in the course of the enterprise's current business. The specialized literature devotes two methods of determination, namely: the deductible method (of difference) and the additive method [27]. In the paper, the deductible method (also known as the difference method or the synthetic method) was used which allows calculation to be made of the value added from the output of the exercise plus the trade margin and deducting the consumption of goods and services provided by third parties for obtaining production.

Return on equity can be considered one of the most important indicators that allows us to identify the company's performance status and measures how efficiently a firm is utilizing debt managed [28]. The interpretation of the size of this indicator must be correlated with the capital structure used. Thus, a high degree of indebtedness, in the context of a smaller share of equity, determines a higher level of return on equity. In a situation of this kind, the shareholders benefit from obtaining a higher profit on the basis of the allocation of a smaller volume of their own capital. However, the risk generated by the high level of debt must not be omitted.

General liquidity allows the company to pay all short-term liabilities at a certain point in time by transforming current assets into liquidity. Considering the calculation formula used, it is obvious that this is influenced by the current assets structure and by the debt volume [29]. Stocks and receivables are of major importance, and an active managerial process is needed to ensure the ability to transform these items into liquidity. General solvency is an important indicator that provides information about the firm's ability to honor its debt, regardless of maturity [30].

For this section, the research method used statistical analyses through multiple regressions and simulation in version 17 of the SPSS software. Data taken from sites was used from www.mfinante.ro and www.bvb.rofor three companies listed on the Bucharest Stock Exchange (Bucharest Stock Exchange, Romania) from the processing industry rubber and plastics (we considered these companies representative of the sector, the statistical population initially analyzed being homogeneous). To ensure greater relevance of the resulting information, the arithmetic mean of the data to be processed was determined (Table 4).

Table 4. Arithmetic mean of data to be processed.

\begin{tabular}{cccccccc}
\hline Year & Rlg & Rs & Eg & Rkpr & Fd & Cimp & Dm-days \\
\hline 2007 & 2.06 & 3.0 & 6.3 & 8.82 & 1.25 & $526,465.33$ & 1.87 \\
2008 & 1.34 & 2.76 & 7.3 & 4.66 & 1.08 & $514,191.66$ & 2.10 \\
2009 & 2.3 & 3.24 & -7.1 & 1.4 & 1.55 & $551,945.33$ & 3.06 \\
2010 & 2.68 & 3.8 & -1.1 & 2.84 & 1.76 & $583,689.66$ & 2.81 \\
2011 & 2.54 & 4.20 & 2.2 & 3.59 & 2.38 & 519,668 & 1.92 \\
2012 & 2.56 & 3.97 & 0.7 & 7.09 & 2.55 & $624,255.33$ & 2.15 \\
2013 & 2.47 & 3.95 & 3.5 & 6.96 & 2.76 & 612,433 & 2.27 \\
2014 & 2.13 & 4.11 & 2.9 & 4.12 & 2.68 & $616,467.33$ & 2.44 \\
2015 & 2.89 & 4.3 & 3.9 & 9.24 & 2.62 & 582,974 & 2.28 \\
2016 & 3.89 & 4.68 & 4.8 & 4.97 & 3.18 & $984,395.66$ & 3.91 \\
\hline
\end{tabular}

Legend: Rlg—general liquidity ratio; Rs—-the solvency ratio; Eg—economic growth rate in Romania; Rkpr-rate of return of equity; $\mathrm{Fd}$-fiscal degree; Cimp—profit tax expense + other taxes; Dm—number of days when the tax liabilities are paid through the revenues from the sales.

In the category of the analyzed indicators, the economic growth rate was included, starting from the consideration that any macroeconomic imbalances can affect the economic activity and the financial situation at the level of the companies. For example, exchange rate volatility or interest rate fluctuations can significantly influence the level of development of economic entities. Also, political instability or repeated changes in tax legislation can lead to a clear decline in the confidence of creditors or potential investors in the economic environment, with direct implications for the liquidity and the level 
of quotes of different stock market shares. The correlation displayed by the SPSS software between turnover and growth rate in Romania is bivariate in nature, the two variables being dependent on each other. The Pearson Coefficient Provided by the Software is 0.700 . The positive value of the correlation coefficient shows that the two indicators were directly correlated during the period 2007-2016, i.e., they had the same trend. The absolute value of the correlation coefficient is close to the middle of the range of 0.50 and number 1 , which shows the strong link between the turnover and the economic growth rate in Romania, namely the strong measure in which the macroeconomic environment influences the activity of economic agents in Romania. The degree of taxation exerts a significant influence on the solvency of the companies (Figure 3).

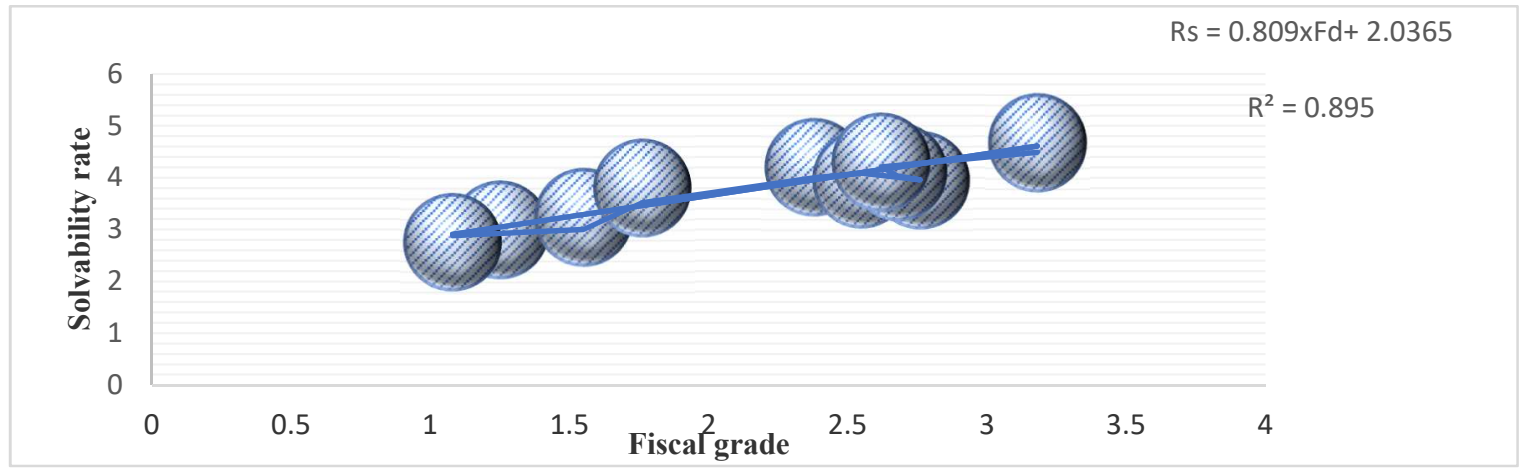

Figure 3. Correlation between the fiscal degree and solvency. Source: own achievement based on data on www.mfinante.ro; www.insse.ro.

Figure 4 shows that the authorities have promoted a pro-cyclical fiscal policy, based on getting as much tax revenue as possible, with direct repercussions on companies' results.

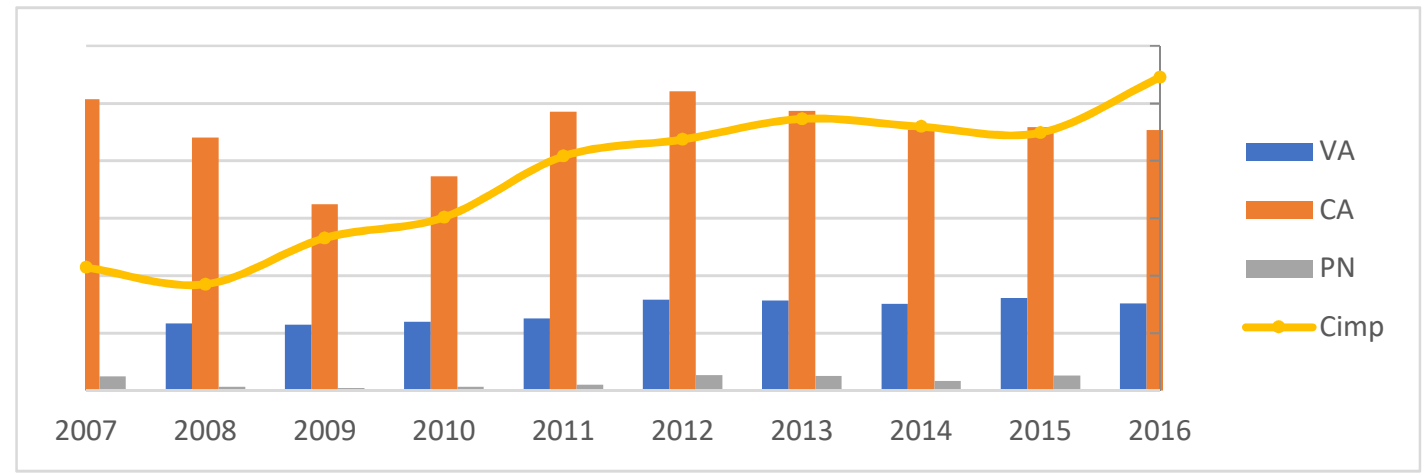

Figure 4. Implication on fiscal degree on companies' results. Source: own achievement based on data on www.bvb.ro.

\subsection{Correlations Matrix}

The financial results obtained by companies are important for several stakeholder categories. Obviously, each category targets a certain interest. For example, managers are tracking their current financial position so they can make a rigorous planning of future business; suppliers relate to short-term debt (liquidity); creditors track solvency and analyze the financial structure, total asset structure and added value; shareholders refer to the rate of return on equity (implicitly to the net profit remaining after the payment of tax liabilities); potential investors relate to their profits and long-term volatility. In this context, it is important to identify a correlation between these indicators, as the management activity requires ensuring convergence between the interests of all the mentioned persons. As a result, the data required for the analysis referred to in Table 5 were systematized. 
Table 5. Arithmetic mean of data to be processed.

\begin{tabular}{ccccccccc}
\hline An & Va & CA & AC & AT & DT & PN & Kpr & EBIT \\
\hline 2007 & $31,389,441.33$ & $101,421,384.3$ & $38,223,324$ & $77,320,221$ & $33,252,960.33$ & $4,869,410$ & $44,177,446.67$ & $8,527,394.66$ \\
2008 & $23,269,593.67$ & $87,971,818.67$ & $42,789,028.33$ & $177,919,088$ & $38,838,964.33$ & $1,286,735$ & $43,882,165.33$ & $6,071,978.33$ \\
2009 & $22,943,430$ & $64,797,453$ & $41,843,247$ & $81,931,111$ & $35,868,781.33$ & $804,585.33$ & $45,958,632$ & $5,573,691.33$ \\
2010 & $23,911,962.66$ & $74,559,239$ & $42,867,674$ & $90,882,326.67$ & $39,161,758.67$ & $1,357,202.66$ & $50,754,912.33$ & $5,517,438$ \\
2011 & $25,110,932.33$ & $96,961,128.33$ & $47,775,587$ & $95,481,616.33$ & $41,706,608$ & $2,068,635.66$ & $52,889,653.67$ & $6,093,006.66$ \\
2012 & $31,553,380$ & $104,167,779.3$ & $52,808,357.33$ & $104,292,412.3$ & $38,323,006.67$ & $5,286,108.66$ & $61,627,174$ & $9,273,460$ \\
2013 & $31,332,778.33$ & $97,386,913.67$ & $51,622,636.33$ & $196,369,288.3$ & $38,326,318.33$ & $5,102,745$ & $62,673,583.33$ & $8,717,392.33$ \\
2014 & $30,161,341.33$ & $90,729,639.67$ & $52,768,866.67$ & $105,248,801$ & $41,437,524$ & $3,360,447$ & $66,141,702$ & $5,728,899$ \\
2015 & $32,139,106.33$ & $91,699,766$ & $57,884,953.67$ & $107,064,952$ & $51,587,801.67$ & $5,203,716$ & $63,380,945$ & $7,565,577.33$ \\
2016 & $30,313,986.67$ & $90,626,415$ & $60,123,833.67$ & $107,168,464.7$ & $42,954,852$ & $3,842,088$ & $66,912,880$ & $5,710,679.66$ \\
\hline
\end{tabular}

Source: financial statements and own computations. Legend: Va-added value; CA-turnover; AC—Current assets;

AT—total assets; DT—total debts; PN—net income; Kpr-equity; EBIT-operating income + financial income.

The analysis showed a correlation between different indicators, as can be seen from the correlation matrix obtained with the SPSS software. The positive value of the Pearson correlation coefficient shows that the variables are directly correlated, i.e., if the values of one have a tendency to increase or decrease, the other have the same trend. The negative value of the Pearson correlation coefficient shows that the variables are indirectly correlated, i.e., whether the values of one have an increasing trend, the other have a downward trend and vice versa. The absolute value of the correlation coefficient very close to one means that the link between the variables was very strong during the period 2007-2016, and the absolute value of the correlation coefficient being very close to zero means that between the variables the link was very weak during this period. Table 6 shows the correlations between the indicators analyzed. According to the matrix of correlations displayed by the SPSS software, each Pearson correlation coefficient in Table 6 had an appropriate significance coefficient to be taken into account.

Table 6. Correlations matrix.

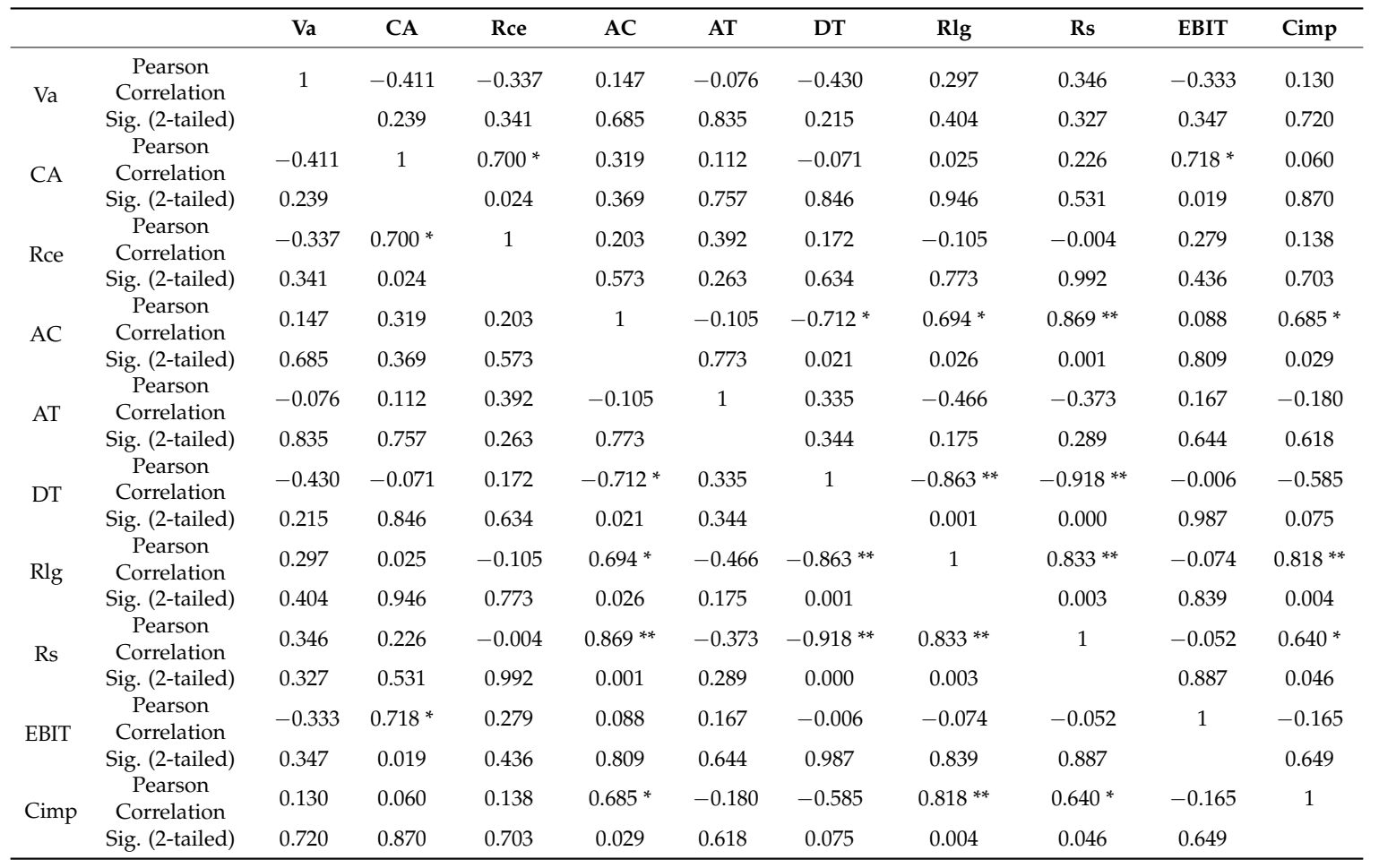

${ }^{*}$ Correlation is significant at the 0.05 level (2-tailed); ${ }^{* *}$ Correlation is significant at the 0.01 level (2-tailed). Source: own computation.Legend: Va—added value; CA—turnover; AC—Current assets; AT—total assets; DT—total debts; $\mathrm{PN}$-net income; Kpr—equity; EBIT—operating income + financial income; Rlg—liquidity ratio; Rs—solvency ratio; Cimp__ profit tax expense + other taxes. 
The positive correlation coefficients show a direct relation between the variables, while the negative ones show an indirect relation between them. The absolute value of the coefficients from the correlation matrix shows that the relation between the variables is: very strong when the absolute value of the Pearson coefficient is close to 1 ; of average intensity when the value of the Pearson coefficient is close to 0.5 ; of very low intensity when the value of the Pearson coefficient is close to zero.

\subsection{Multiple Regression Analysis}

In order to study the existence of a cause-and-effect relationship between the way in which taxation influences the capacity to create added value and to ensure financial equilibrium, an analysis of the multiple regression of the indicators was carried out.

In this respect, the proposed model includes the following variables: dependent variable: $Y$-value added; the variables that $Y$ will depend on, are the other indicators used in the article and whose values are presented in Tables 4 and 5 .

The calculation formula using the regression model is of the form:

$$
Y=a_{0}+\sum_{i} a_{i} X_{i} \pm \varepsilon
$$

where: $a_{0}$ is originally ordered; $a_{i}$ is the regression coefficients, showing the degree of dependence between variables (as the average $Y$ changes to an increase or decrease with a unit of the variable $X_{i}$ ); and $\varepsilon$ is the residual factor.

The variables are normally distributed; the verification can be easily done in the SPSS software.

For Multiple Linear Regression Analysis, in the SPSS 17 program, we selected the dependent variable and nine variables on which it will depend. The software has shown the results in Table 7:

Table 7. Coordinates of multiple linear regression displayed by the SPSS 17 software.

\begin{tabular}{cc}
\hline & Unstandardized Coefficients \\
\hline Constant $)$ & $-9.029 \times 10^{8}$ \\
Fiscal value $\left(C A \equiv X_{1}\right)$ & -8.351 \\
Economic growth rate in Romania $\left(\mathrm{Eg} \equiv X_{2}\right)$ & $8,511,327.731$ \\
Current assets $\left(A C \equiv X_{3}\right)$ & -12.600 \\
Total Assets $\left(A T \equiv X_{4}\right)$ & 0.113 \\
Total debts $\left(D T \equiv X_{5}\right)$ & 107.939 \\
General liquidity rate $\left(R l g \equiv X_{6}\right)$ & $-3.931 \times 10^{7}$ \\
Solvency ratio $\left(R s \equiv X_{7}\right)$ & $3.524 \times 10^{8}$ \\
Operating result + Financial income $\left(E B I T \equiv X_{8}\right)$ & 51.555 \\
Other taxes $\left(C i m p \equiv X_{9}\right)$ & 162.936 \\
\hline
\end{tabular}

The software displays the calculation error with 3 decimals. The following decimals, the 4 th, 5 th decimal etc., might be different from zero. The value of the significance threshold $p$, displayed by the software, is lower than 0.05 , therefore the results are statistically significant.

By replacing the results in Table 5, in relation (1), we obtained the mathematical mode of the multiple regression equation:

$$
\begin{aligned}
& Y \equiv V a \equiv-9.029 \times 10^{8}-8.351 \times C A+8,511,327.731 \times E g-12.6 \times A C+0.113 \times A T+ \\
& 107.939 \times D T-3.931 \times 10^{7} \times R l g+3.524 \times 10^{8} \times R s+51.555 \times E B I T+162.936 \times C i m p
\end{aligned}
$$

where: $a_{0}=-9.029 \times 10^{8}, a_{1}=-8.351, a_{2}=8,511,327.731, a_{3}=-12.6, a_{4}=0.113, a_{5}=107.939$, $a_{6}=-3.931 \times 10^{7}, a_{7}=3.524 \times 10^{8}, a_{8}=51.555, a_{9}=162.936, \varepsilon=0$.

The mathematical relation shows how $V a$ changes, on average, in case of an increase/decrease with 1 unit of the $C A, E g, A C, A T, D T, R l g, R s, E B I T$, or Cimp variable. 
We have chosen the significance threshold of 0.05 . According to the significance coefficient displayed by the SPSS software, the model can be considered significant with a confidence level of over $95 \%$.

The analysis shows that the reduction in the number of rotations at the level of the current assets (which have a large share in the total assets used by the companies in the field of rubber and plastics processing) has negatively influenced the added value. The increase in tax liabilities determines the increase in the share of the added value that is allocated to the state, being dependent on the share of the material costs (and implicitly the consumption from third parties), the salary costs and the level of profitability. Reducing general liquidity, in the context of rising of current debts, influences to a lesser extent the added value in the same direction, amid increased of consumptions from third parties. As a result, the firms in the analyzed sector have to calculate the level of tax pressure exerted by taxes because it is not dependent only on the results obtained and the dynamics of the base but also the modification of external factors that influence the order of calculation and the payment of taxes [29].

\section{Discussion}

The analysis carried out in this study confirmed the hypothesis from which we started, demonstrating empirically the influence exerted by the degree of taxation on economic agents and implicitly on the business environment. We tried to provide policy makers with the evidence that the fiscal policy is an extremely important factor to ensure the development of entire economy. The study and the results highlighted the following: legislative changes in the fiscal plan generate instability in the business environment; tax obligations (which can be considered negative cash flows) exert a significant influence on the profit remaining at the disposal of economic agents and, implicitly, on the future self-financing capacity; the future performance level is affected by the degree of taxation in the context of using a linear profit tax.

The study is relevant through the fact that it identifies the correlation between the degree of taxation generated by the fiscal policy promoted by the state and the state of equilibrium and performance at the level of economic agents, making a transposition from macroeconomic at microeconomic level. Practically, we have focused on the effects of changes in tax obligations regulated by the authorities related to economic growth and the financial equilibrium, with direct implications on performance. The research shows that fiscal policy can influence the economic activity of companies, with direct implications for the sustainable development of an economy. We believe that a change in the degree of taxation can influence economic development, both at the macro- and micro- economic levels, if it is the result of measures that stimulate work, investments and saving. The results obtained do not contradict the previous researches, which include the degree of taxation in the category of factors that influence the activity at microeconomic level, but aims to clarify that financial equilibrium can be provided by managers in the context of practicing a fiscal management activity.

From the analysis of the obtained results, the following conclusions can be drawn: Repeated legislative changes, established without consulting the business environment and without real anchoring in the economy, are generating destabilization across society; as a result, it is necessary to ensure legislative stability, so that any economic agent can develop a long-term balanced strategy and budget; the stimulation of economic agents in the sense of achieving investments; broadening the tax base (to the detriment of establishing new tax obligations or raising tax rates).

These aspects are in accordance with [31-33]. The results suggest that, for the analyzed sector, the return on equity, the level of debt, the structure of capital, the level of sales and the net profit are elements which, according to the economic growth rate and fiscal degree, are essential for the strategic business management in the context of the need to ensure the sustainability of financial performance of companies [34]. Also, in accordance with [35], taxation remains an instrument that can be used by authorities to stimulate the development of a circular economy model so as to ensure sustainable development. Managing the tax burden, in conjunction with the company's strategic objectives, can determine a reduction in tax costs and risk. Thus, the use of appropriate damping 
methods, the analysis of the tax incidence both in terms of payments made and the savings recorded on the basis of tax incentives are absolutely necessary in the process of optimizing the treasury and the influence of the fiscal parameter on the performed activity. The results of this study highlight the fact that firms must include macroeconomic conditions in future performance forecasting models. This paper contributes to the extant literature because provide evidence of the relationship between financial equilibrium, and performances of companies under the influence of taxation. Most studies conducted have focused on certain indicators. Our findings extend the understanding of correlation between indicators who determine the changes of added value. Also, we have achieved a reflection of the influences exerted by the macroeconomic context on business environment, in terms of profitability and equilibrium, in the context of the fiscal policy promoted by authorities in different periods. Third, we introduced nine variables into a statistical model, to identify their influences on added value, because this have been approached separately or in a smaller number in majority of previous studies.

\section{Conclusions}

The business environment is an important engine in any economic mechanism. As a result, its development must be a desideratum of any strategy at macroeconomic level. Unfortunately, the authorities have not always supported, by appropriate measures, the business sector, most often placing the desire to obtain tax revenue as quickly and as high as possible. Repeated legislative changes that directly or indirectly influence the entrepreneurial environment do not provide a favorable framework for the development of this sector. To these are added other factors from the internal or external environment. In this context, taxes and fees influence the financial position of firms by changes in the volume and structure of assets and liabilities, or by changes in volume and structure of expenses and profit/loss. From the data processing presented, it results that the level of the balance indicators is influenced by external factors (economic growth rate, tax rate), as well as by internal factors (financial structure, liquidity level or asset structure). However, a general conclusion highlights the fact that the negative economic phenomena of scale show the fragility of the business environment in front of them as well as the absence of a compensatory mechanism in the management process in risk management.

However, it is important to make clear that there are some limits to the research carried out. First, using data for a small number of observations can affect the statistical significance of the results. Secondly, it is necessary to separate the analysis by categories of tax obligations and, moreover, to identify the influence of indirect taxes on the turnover and the level of competitiveness of the economic agents through the used prices. Also, in future research, it would be useful to identify the optimal level of taxation that allows for obtaining the economic and financial results consistent with established performance targets.

Author Contributions: The three authors contributed equally to this work (Conceptualization, A.B., G.D. and O.D.; Formal analysis, A.B., G.D. and O.D.; Funding acquisition, A.B.; Investigation, A.B., G.D. and O.D.; Methodology, A.B., G.D. and O.D.). All authors have read and approved the manuscript.

Funding: This research was funded by Lucian Blaga University of Sibiu, grant number LBUS-IRG-2018-04.

Acknowledgments: Project financed from Lucian Blaga University of Sibiu research grants LBUS-IRG-2018-04.

Conflicts of Interest: The authors declare no conflict of interest.

\section{References}

1. Laffer, A.B. The Laffer Curve: Past, Present, and Future, The Heritage Foundation; The Heritage Foundation: Washington, DC, USA, 2004.

2. Richardson, G.; Lanis, R. Determinants of the variability in corporate effective tax rate and tax reform. Evidence from Australia. J. Account. Public Policy 2007, 26, 689-704. [CrossRef]

3. Gupta, S.; Newberry, K. Determinants of the variability in corporate effective tax rates: Evidence from longitudinal data. J. Account. Public Policy 1997, 16, 1-34. [CrossRef] 
4. Stickney, C.; McGee, V. Effective corporate tax rates the effect of size, capital intensity, leverage and other factors. J. Account. Public Policy 1982, 1, 125-152. [CrossRef]

5. Overesch, M.; Voeller, D. The impact of Personal and Corporate Taxation on Capital Structure Choices. Public Financ. Anal. 2010, 66, 263-294. [CrossRef]

6. Givoly, D.; Hahn, C.; Ofer, A.R.; Sarig, O.H. Taxes and capital structure: Evidence from firms' response to the Tax Reform Act of 1986. Rev. Financ. Stud. 1992, 5, 331-355.

7. Clemente-Almendros, J.; Sogorb-Mira, F. The effects of taxes on the debt policy of spanish listed companies. SERIEs 2016, 7, 359-391. [CrossRef]

8. Feld, L.P.; Heckemeyer, J.H.; Overesch, M. Capital structure choice and company taxation: A meta-study. J. Bank Financ. 2013, 37, 2850-2866. [CrossRef]

9. Doidge, C.; Dyck, A. Taxes and corporate policies: Evidence from a quasinatural experiment. J. Financ. 2015, 70, 45-89. [CrossRef]

10. Faccio, M.; Xu, J. Taxes and capital structure. J. Financ. Quant. Anal. 2015, 50, 277-300. [CrossRef]

11. Heider, F.; Ljungqvist, A. As certain as debt and taxes: Estimating the tax sensitivity of leverage from State tax changes. J. Financ. Econ. 2015, 118, 684-712. [CrossRef]

12. Parise, T.V.; Shenai, V. The Value Effect of Financial Reform on U.K. Banks and Insurance Companies. Int. J. Financ. Stud. 2018, 6, 81. [CrossRef]

13. Townsed, R. Financial Structure and Economic Welfare: Applied General Equilibrium Development Economics. An. Rev. Econom. 2010, 2, 507-546. [CrossRef]

14. Žager, K.; Sačer, I.M.; Dečman, N. Financial ratios as an evaluation instrument of business quality in small and medium-sized enterprises. Int. J. Manag. Cases 2012, 14, 373-385.

15. Ji, J.; Ye, Z.; Zhang, S. Welfare analysis on optimal enterprise tax rate in China. Econ. Model. 2013, 33, 149-158. [CrossRef]

16. Latorre, M.C. On the Differential Behaviour of National and Multinational Firms: A Within- and Across-sectors Approach. World Econ. 2013, 36, 1294-1317. [CrossRef]

17. Mihăilă, N. Fiscal behavior of the economic agent. Factor of influence. Rev. Strateg. Manag. 2013, 4, 33-48.

18. Sokolovskyi, D.; Sokolovska, O. Tax Burden Optimization on Economic Agents by Modeling Interaction in the Taxation System; MPRA Paper No. 71110. Available online: https:/ / mpra.ub.uni-muenchen.de/71110/ 1/MPRA_paper_71110.pdf (accessed on 19 January 2019).

19. Kuo, T.C.; Hong, I.H.; Lin, S.C. Do carbon taxes work? Analysis of government policies and enterprise strategies in equilibrium. J. Clean. Prod. 2016, 139, 337-346. [CrossRef]

20. Pitulice, I.; Ștefănescu, A.; Mînzu, V.G.; Popa, A.F.; Niculescu, A.M. Research of corporate tax impact on financial performance, case of companies listed on Bucharest Stock Exchange. Manag. Econ. Rev. 2016, 1, 203-216.

21. Brezeanu, P.; Damian, R.T. Analiza Presiunii Fiscale din Statele Membre ale Uniunii Europene (I). Available online: http:/ / www.ceccarbusinessmagazine.ro/analiza-presiunii-fiscale-din-statele-membre-ale-uniuniieuropene-i-a2670/ (accessed on 19 January 2019).

22. Simionescu, L.N.; Dumitrescu, D. Empirical Study towards Corporate Social Responsibility Practices and Company Financial Performance. Evidence for Companies Listed on the Bucharest Stock Exchange. Sustainability 2018, 10, 3141. [CrossRef]

23. Aquilani, B.; Silvestri, C.; Ruggieri, A. Sustainability, TQM and Value Co-Creation Processes: The role of critical success factors. Sustainability 2016, 8, 995. [CrossRef]

24. Busu, M.; Nedelcu, A.C. Sustainability and Economic Performance of the companies in the renewable energy sector in Romania. Sustainability 2017, 10, 8. [CrossRef]

25. Dobrotă, G. Correlations between fiscal-Budgetary policy and the economic development in Romania. Ann. Econ. Ser. 2012, 3, 98-103.

26. Paying Taxes. Thirteen Years of Data and Analysis on Systems in 190 Economies: A Look at Recent Developments and historical Trends, Report of World Bank Group. 2018. Available online: https: / www. pwc.com/payingtaxes (accessed on 18 February 2019).

27. Ișfănescu, A.; Robu, V.; Hristea, A.M.; Vasilescu, C. Analiza Economico-Financiară; ASE Publishing House: Bucharest, Romania, 2002.

28. Lee, D.D.; Faff, R.W.; Langfield-Smith, K. Revisiting the Vexing Question: Does Superior Corporate Social Performance Lead to Improved Financial Performance? Aust. J. Manag. 2009, 34, 21-49. [CrossRef] 
29. Brătian, V.; Bucur, A.; Opreana, C. Finanţe Cantitative_Evaluarea Valorilor Mobiliare şi Gestiunea Portofoliului; "Lucian Blaga" University of Sibiu Publishing House: Sibiu, Romania, 2016. (In Romanian)

30. Berman, K.; Knight, J.; Case, J. Financial Intelligence: A Manager's Guide to Knowing What the Numbers Really Mean, Business Literacy Institute; Curtea Veche Publishing House: București, Romania, 2007; p. 175. (In Romanian)

31. Khidmat, W.B.; Rehman, M.U. Impact of Liquidity \& Solvency on Profitability Chemical Sector of Pakistan. Econ. Manag. Innov. 2014, 6, 3-13.

32. Méndez-Picazo, M.T.; Galindo-Martín, M.-A.; Ribeiro-Soriano, D. Governance, Entrepreneurship and Economic Growth. Entrep. Reg. Dev. Int. J. 2012, 24, 865-877. [CrossRef]

33. Todorovic, I. Impact of Corporate Governance on Performance of Companies. Montenegrin J. Econ. 2013, 9, 47-53.

34. Zubair, S.S.; Khan, M.A. Good Governance: Pakistan's Economic Growth and Worldwide Governance Indicators. Pak. J. Commer. Soc. Sci. 2014, 8, 258-271.

35. Dobrotă, G.; Dobrotă, D.; Petrescu, V. Circular economy-Foundament of challenges for business environment. In Proceedings of the Balkan Region Conference on Engineering and Business Education, Sibiu, Romania, 19-22 October 2017. [CrossRef]

(C) 2019 by the authors. Licensee MDPI, Basel, Switzerland. This article is an open access article distributed under the terms and conditions of the Creative Commons Attribution (CC BY) license (http://creativecommons.org/licenses/by/4.0/). 